\title{
OPEN ACCESS \\ Foraging effort in Magellanic penguins in coastal Patagonia, Argentina
}

\author{
J. E. Sala ${ }^{1, *}$, R. P. Wilson ${ }^{2}$, E. Frere ${ }^{3,4}$, F. Quintana ${ }^{1,4}$ \\ ${ }^{1}$ Centro Nacional Patagónico (CONICET), Boulevard Brown 2915 (U9120ACD), Puerto Madryn, Chubut, Argentina \\ ${ }^{2}$ Biosciences, College of Science, Swansea University, Swansea SA2 8PP, UK \\ ${ }^{3}$ Centro de Investigaciones Puerto Deseado (UNPA-CONICET), Av. Prefectura S/N (9050), Puerto Deseado, Santa Cruz, \\ Argentina \\ ${ }^{4}$ Wildlife Conservation Society, Amenabar 1595 (C1426AKC), Ciudad Autónoma de Buenos Aires, Argentina
}

\begin{abstract}
In long-lived species such as seabirds, foraging success is considered to be related to breeding success, so quantification of foraging parameters during the breeding season should help understand population trends. Using GPS units, we studied the foraging effort of 55 breeding Magellanic penguins Spheniscus magellanicus from 5 colonies in coastal Patagonia, Argentina (42 to $54^{\circ}$ S): Punta Norte, Bahía Bustamante, Puerto Deseado, Puerto San Julián and Isla Martillo, in an attempt to relate this to differences in breeding population trends. Measures of foraging effort - trip duration, total distance covered and maximun distance of the foraging trips from the breeding colony-decreased with increasing rate of population change. This information suggests that there are large differences in foraging effort and success among Patagonian penguin colonies, and penguins from Bahía Bustamante and Puerto Deseado, which are in the centre of the geographic range, require the highest foraging effort but are the least successful. It is plausible that lower population growth rates in these 2 colonies stem from the differences in food availability rather than any other process on land.
\end{abstract}

KEY WORDS: Magellanic penguin - Spheniscus magellanicus $\cdot$ Foraging effort $\cdot$ Population trends $\cdot$ GPS tracking $\cdot$ Patagonia

\section{INTRODUCTION}

The strategy to breed in colonies is widespread in birds, especially in seabirds, where $98 \%$ of the species breed colonially (Rolland et al. 1998). The conditions modulating colony size within species appear complex (Brown \& Brown 2000), but aside from limitations imposed by the availability of breeding sites (e.g. Duffy 1983), food availability is often given as the reason to explain much of the variability in colony size (Lack 1968). This idea dates back to Ashmole (1963), who predicted that colony size should affect the foraging effort of central place foragers such as seabirds, with birds from larger colonies having to work harder to obtain food due to densitydependent intraspecific competition caused either by localized prey depletion or reduced prey availability due to interference (Lewis et al. 2001). Empirical support for Ashmole's (1963) hypothesis comes from the relationships between colony size and spacing (Furness \& Birkhead 1984), reproductive success and chick growth (Hunt et al. 1986) and direct measures of foraging effort and reduced prey density close to colonies (Lewis et al. 2001, Forero et al. 2002). Although a number of studies specifically looking at foraging effort have provided partial support for Ashmole's (1963) hypothesis (e.g. Lewis et al. 2001, Gaston et al. 2007), the specifics of how foraging effort, coupled with food availability, might modulate population numbers and trends are often poorly elucidated (but see Grémillet et al. 2006, Lewis et al. 2006, Pichegru et al. 2007). Lewis et al. (2006) recently sug- 
gested that in long-lived species such as seabirds, foraging parameters recorded during the breeding season could be used to improve understanding population limits and changes. Foraging trips can be studied within a much shorter time frame than population studies, and therefore can be used as a rapid base for management strategies (Grémillet et al. 2006, Pichegru et al. 2007). This is particularly germane since population studies of long-lived, endangered species often provide the only warning signals after the situation has degraded beyond the point of no return (Beissinger \& Westphal 1998). This explains the recent surge in interest in foraging metrics, such as trip duration, foraging path length, maximum distance from the colony and travel speed, all of which can act as behavioural proxies reflecting population trends (Lewis et al. 2006, Petersen et al. 2006). Based on this approach, Grémillet et al. (2006) demonstrated that foraging effort can be used as a powerful short-term indicator of population health in the northern gannet Morus bassanus. This process is facilitated by recent advances in miniaturized electronic instruments (Wilson \& Vandenabeele 2012), which provide opportunities to accurately correlate behavioural traits with food availability as well as energy expenditure in free-living species (Petersen et al. 2006, Wilson et al. 2008). To determine how foraging effort relates to population trends in seabirds, a number of authors have used GPS loggers (Grémillet et al. 2006, Lewis et al. 2006, Petersen et al. 2006, Pichegru et al. 2007). Most of these studies have been undertaken during the rearing phase, because this is the most demanding period due to the additional food requirements of the brood, constraints of central place foraging and consumptive intraspecific competition (Forero et al. 2002, Grémillet et al. 2006, Lewis et al. 2006, Petersen et al. 2006).

Among seabirds, penguins are the most highly specialized for swimming and diving (Williams 1995) and therefore should reflect regional oceanic variation in 3 dimensions particularly well (e.g. Cotté et al. 2007). Indeed, studies have used penguins to allude to changes in oceanographic productivity and humaninduced changes in the environment, including fishing pressure, climate variation and oil pollution (Boersma 2008, Boersma et al. 2009, Yorio et al. 2010).

Magellanic penguins Spheniscus magellanicus breed at mainland and island colonies on both coasts of South America, as far north as $41^{\circ} \mathrm{S}$ on the Atlantic coast, as well as on the Malvinas/Falkland Islands (Williams 1995, Schiavini et al. 2005). The species is classified as 'Near Threatened', because the population is declining (Birdlife International 2012). There is concern for this species because in Patagonia, Argentina, the species is currently affected by commercial and artisanal fishing activities (Yorio et al. 2010), competition for food with the fisheries (Frere et al. 1996a), oil pollution and other contaminants such as lead and organochlorine pesticides (GarcíaBorboroglu et al. 2006). In the area of the Patagonian shelf, Magellanic penguins eat primarily small pelagic fishes (Engraulis anchoita, Sprattus fuegensis, Sardinops sp.), hake Merluccius hubbsi and squid (Illex sp., Loligo sp.) (Williams 1995, Frere et al. 1996b, Wilson et al. 2005), which are all taxa frequently associated with oceanographic frontal systems (Acha et al. 2004). Population trends of the Patagonian coast Magellanic penguin colonies do not follow a common pattern. An increase in the number of breeding pairs has been recorded in penguin colonies located in the north of Península Valdés as well as in the north of Golfo San Jorge (Schiavini et al. 2005, Croxall et al. 2008; Fig. 1). In contrast, the colony at Punta Tombo (the largest Magellanic penguin colony in the world and located between the Península Valdés and Golfo San Jorge; Fig. 1) has decreased by $22 \%$ in the number of breeding pairs since 1987 (Boersma 2008, Croxall et al. 2008).

We used GPS technology attached to free-living Magellanic penguins to examine a suite of foraging parameters of birds from 5 colonies ranging in distribution from the north of their latitudinal range in Argentina to the most southerly sites (Fig. 1) and examined these parameters with respect to population status and changes. We expected foraging birds to be working hardest in the colonies where populations are doing less well and examined the hypothesis that the foraging effort of Magellanic penguins can explain the general population status and trends found in the colonies of Patagonia, Argentina.

\section{MATERIALS AND METHODS}

\section{Study sites, device deployments and data logger specifications}

Field work was conducted in 5 Magellanic penguin colonies along the Patagonian coast of Argentina. Colonies were classified as those located in the north: Punta Norte $\left(42^{\circ} 04^{\prime} \mathrm{S}, 63^{\circ} 49^{\prime} \mathrm{W}\right)$; centre: Bahía Bustamante $\left(45^{\circ} 10^{\prime} \mathrm{S}, 66^{\circ} 29^{\prime} \mathrm{W}\right)$ and Puerto Deseado $\left(47^{\circ} 45^{\prime} \mathrm{S}, 65^{\circ} 52^{\prime} \mathrm{W}\right)$; and south: Puerto San Julián $\left(49^{\circ} 16^{\prime} \mathrm{S}, 67^{\circ} 42^{\prime} \mathrm{W}\right)$ and Isla Martillo, Beagle Channel (54 $\left.54^{\prime} \mathrm{S}, 67^{\circ} 22^{\prime} \mathrm{W}\right)$ (Fig. 1, Table 1). This classification was undertaken according to geographic 


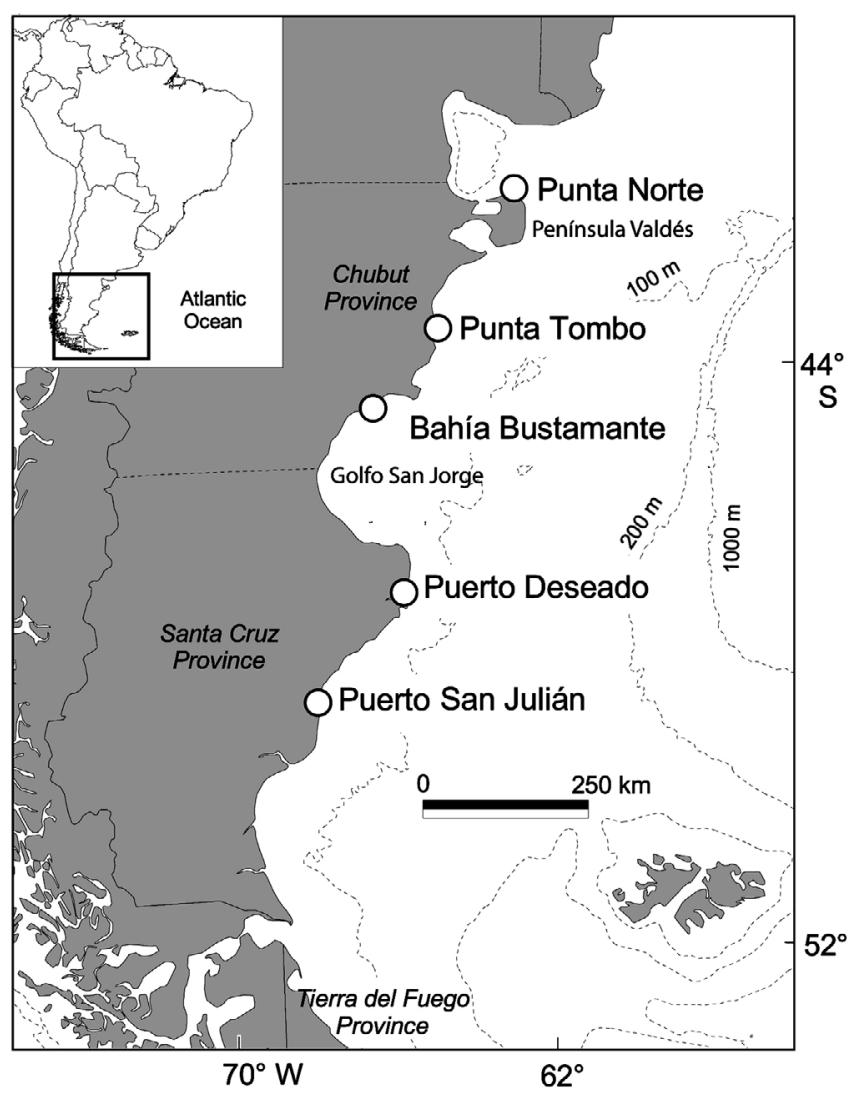

Fig. 1. Location of the 5 colonies in Argentina where Magellanic penguins were equipped with devices. Punta Tombo, the largest colony for this species was also incorporated in to the analysis using data published in the literature (see 'Materials and methods'). Numbers of devices deployed per colony are given in Table 2

(latitude) as well as after consideration of the diet composition per region (e.g. birds are mainly monophagic in the north and south, but take a broader spectrum of prey species in the centre; Frere et al. 1996b, Wilson et al. 2005, Boersma et al. 2009). Fieldwork was carried out during the early chick-rearing period between November and December of the 2006, 2007 and 2008 breeding seasons (Table 2).

Sixty Magellanic penguins were equipped with GPS loggers (GPS-TDlog, Earth and Ocean Technologies), which recorded time, latitude, longitude and speed data every second. As in previous studies there were no reported differences between sexes for the variables studied (e.g. Boersma \& Rebstock 2009, Raya Rey et al. 2010), so the data were pooled without distinction between sexes (although the proportion of instrumented males and females from each colony was similar). The horizontal accuracy of positional fixes derived from the GPS units was considered to be better than $5 \mathrm{~m}$ for $90 \%$ of the fixes (GPSTDlog Manual). The loggers measured $96 \times 48 \times$ $24 \mathrm{~mm}$ and weighed $70 \mathrm{~g}$, less than $1.6 \%$ of adult body mass (mean $4.4 \mathrm{~kg}$, range 2.7 to $7.2 \mathrm{~kg}$ ) (Williams 1995). All of the 60 devices placed were recovered, although 5 of them showed no consistent GPS positions (latitude, longitude) and thus were discarded from the analysis. We consequently report information from 55 Magellanic penguins (Table 2). Birds were gently removed from their nests while they brooded chicks, and devices were attached to the feathers of the lower back using waterproof tape (Wilson et al. 1997) to minimize hydrodynamic drag (Bannasch et al. 1994). Every effort was taken to minimize the stress caused to the birds during manipulation. The attachment procedure was completed in less than 5 min and the birds were therefore quickly returned to their nests. GPS devices were retrieved after a single foraging trip and recovered at the moment when birds came back from the sea to return to the nest. All birds equipped with devices continued breeding during the study period. All field activities were conducted under the appropriate permits of the different provincial offices of conservation and protected areas.

Table 1. Spheniscus magellanicus. Location, population size (number of pairs) and rate of population change (RPC, \%) from the 6 colonies of Magellanic penguins analyzed in this study. Values are presented for the last available census and the year of its realization. N: number of counts of breeding pairs (census) available for each colony

\begin{tabular}{|c|c|c|c|c|c|}
\hline Colony & Location & Size & Year & $\mathrm{RPC}(\mathrm{N})$ & Source \\
\hline Punta Norte & $42^{\circ} 04 \mathrm{~S}, 63^{\circ} 49 \mathrm{~W}$ & 56737 & 2003 & $12.03(2)$ & Schiavini et al. (2005) \\
\hline Punta Tombo & $44^{\circ} 02 \mathrm{~S}, 65^{\circ} 11 \mathrm{~W}$ & $\sim 128000^{\mathrm{a}}$ & 2006 & $-1.21(15)$ & Boersma (2008) \\
\hline Bahía Bustamante & $45^{\circ} 10 \mathrm{~S}, 66^{\circ} 29 \mathrm{~W}$ & 32337 & 2003 & $3.99(2)$ & Schiavini et al. (2005) \\
\hline Puerto Deseado & $47^{\circ} 55 \mathrm{~S}, 65^{\circ} 52 \mathrm{~W}$ & 20287 & 2007 & $-1.21(4)$ & E. Frere (unpubl. data) \\
\hline Puerto San Julián & $49^{\circ} 16 \mathrm{~S}, 67^{\circ} 42 \mathrm{~W}$ & 56792 & 2005 & $3.54(2)$ & E. Frere (unpubl. data) \\
\hline Isla Martillo & $54^{\circ} 54 \mathrm{~S}, 67^{\circ} 22 \mathrm{~W}$ & 2000 & 2005 & $10.06(3)$ & Schiavini et al. (2005) \\
\hline
\end{tabular}


Table 2. Spheniscus magellanicus. Summary of GPS telemetry data obtained from 55 of 60 instrumented Magellanic penguins from Patagonian colonies during the early chick-rearing period. Number of birds with data was used to perform kernel analysis; number of birds with complete trips was used to calculate the foraging variables

\begin{tabular}{|c|c|c|c|c|c|}
\hline Colony & $\begin{array}{l}\text { Study } \\
\text { year }\end{array}$ & $\begin{array}{l}\text { No. of } \\
\text { instru- } \\
\text { mented } \\
\text { birds }\end{array}$ & $\begin{array}{l}\text { No. of } \\
\text { birds } \\
\text { with } \\
\text { data }\end{array}$ & $\begin{array}{l}\text { No. of } \\
\text { birds with } \\
\text { complete } \\
\text { trips }\end{array}$ & $\begin{array}{l}\text { Recording } \\
\text { period } \\
(\mathrm{dd} / \mathrm{mm})\end{array}$ \\
\hline Punta Norte & 2008 & 12 & 12 & 10 & $28 / 11-01 / 12$ \\
\hline \multirow[t]{2}{*}{ Bahía Bustamante } & 2006 & 5 & 5 & 3 & $29 / 11-03 / 12$ \\
\hline & 2007 & 13 & 10 & 6 & $03 / 12-10 / 12$ \\
\hline Puerto Deseado & 2006 & 4 & 4 & 3 & $04 / 12-08 / 12$ \\
\hline Puerto San Julián & 2007 & 15 & 13 & $11^{\mathrm{a}}$ & $10 / 12-17 / 12$ \\
\hline \multirow[t]{2}{*}{ Isla Martillo } & 2006 & 7 & 7 & $5^{\mathrm{b}}$ & $03 / 12-07 / 12$ \\
\hline & 2007 & 4 & 4 & 3 & $07 / 12-10 / 12$ \\
\hline Total & & 60 & 55 & 41 & \\
\hline
\end{tabular}

\section{Data analysis}

Spatial analyses were undertaken with ArcView 3.2 (ESRI) by using the Animal Movement extension to ArcView v. 2.0 for kernel analysis to assess habitat use from GPS locations (fixed kernel method) (Worton 1989). We used a smoothing factor $h=3000 \mathrm{~m}$ with cell size of $1000 \mathrm{~m}$ to determine kernel contours of 50,75 and $95 \%$. The smoothing factor was chosen according to the least-squares cross-validation method (Girard et al. 2002). Distribution maps were produced for the complete data set of the foraging trips. We estimated the density of birds foraging at sea using the actual number of penguins with position records divided by the area within 95\% kernel contours.

Five behavioural variables were derived from the loggers and were calculated for each of the instrumented penguin - (1) trip duration (h): time elapsed between the first position recorded in the water during the outward leg of the foraging trip and the point at which the bird first touched land at the colony on the return leg; (2) trip length $(\mathrm{km})$ : total cumulative horizontal distance between all positional fixes along the foraging track ${ }_{i}$ (3) maximum distance from the colony $(\mathrm{km})$ : maximum straight-line distance at any time during the foraging trip between the bird and its nest site; (4) maximum straight-line distance to the coast $(\mathrm{km})$ : greatest straight-line distance between the bird and the nearest point on the coast at any point during the foraging trip; (5) overall track tortuosity: total straight-line distance between the first and last point of the trip phase divided by the sum of the consecutive distances between all pairs of points within that trip phase (see below).

All behavioural data were derived from our own database except for the birds from Punta Tombo where mean $( \pm \mathrm{SD})$ values of the maximum distance from the colony $(92 \pm 6.5 \mathrm{~km})$ and trip duration were taken from Boersma \& Rebstock (2009) and Boersma et al. (2007), respectively. Knowing that trip length and maximum distance from the colony showed a significant and positive linear relation$\operatorname{ship}\left(\mathrm{R}^{2}=0.82, F_{1,43}=200, \mathrm{p}<0.0001, \mathrm{n}=\right.$ 44 trips; all data pooled), we used this linear relationship to estimate the average trip length.

Each foraging trip was divided into 3 phases on the basis of fix classifications, which involved comparing running mean speed values during a 30 min period with the mean swimming speed for the whole trip (Fig. 2a). We assumed that Magellanic penguins decrease their travelling speed during foraging due to a general decrease in their horizontal displacement, while vertical movement increases due to deeper diving depths. This accords with observations by various authors (Cotté et al. 2007 for king penguins Aptenodytes patagonicus, Petersen et al. 2006 for African penguins Spheniscus demersus and Wilson et al. 2005, Boersma \& Rebstock 2009, Boersma et al. 2009, Raya Rey et al. 2010 for Magellanic penguins). The 3 phases were defined as (1) outbound phase, i.e. the travel period between the colony and the foraging area, where the running means of swimming speeds were higher than the mean speed of the whole trip; (2) foraging, which began when the birds first slowed down to a speed lower than that of the overall mean of the trip (point $i$ in Fig. 2a) and finished when the running mean increased above the overall mean for the last time (point ii in Fig. 2a); (3) inbound, the period between the end of the foraging phase (see above) and the return to the colony. Classification of fixes as part of 1 of the 3 phases was obtained by an algorithm developed with the open source statistical package R v.2.13.0 ( $R$ Development Core Team 2011), which allowed us to select the limits of each phase on the graphs (points $i$ and ii in Fig. 2a) interactively. To measure the tortuosity of penguin tracks for each trip phase, we used the index following Boersma et al. (2009), called the net-to-gross displacement ratio (NTGDR). We divided the straight- 

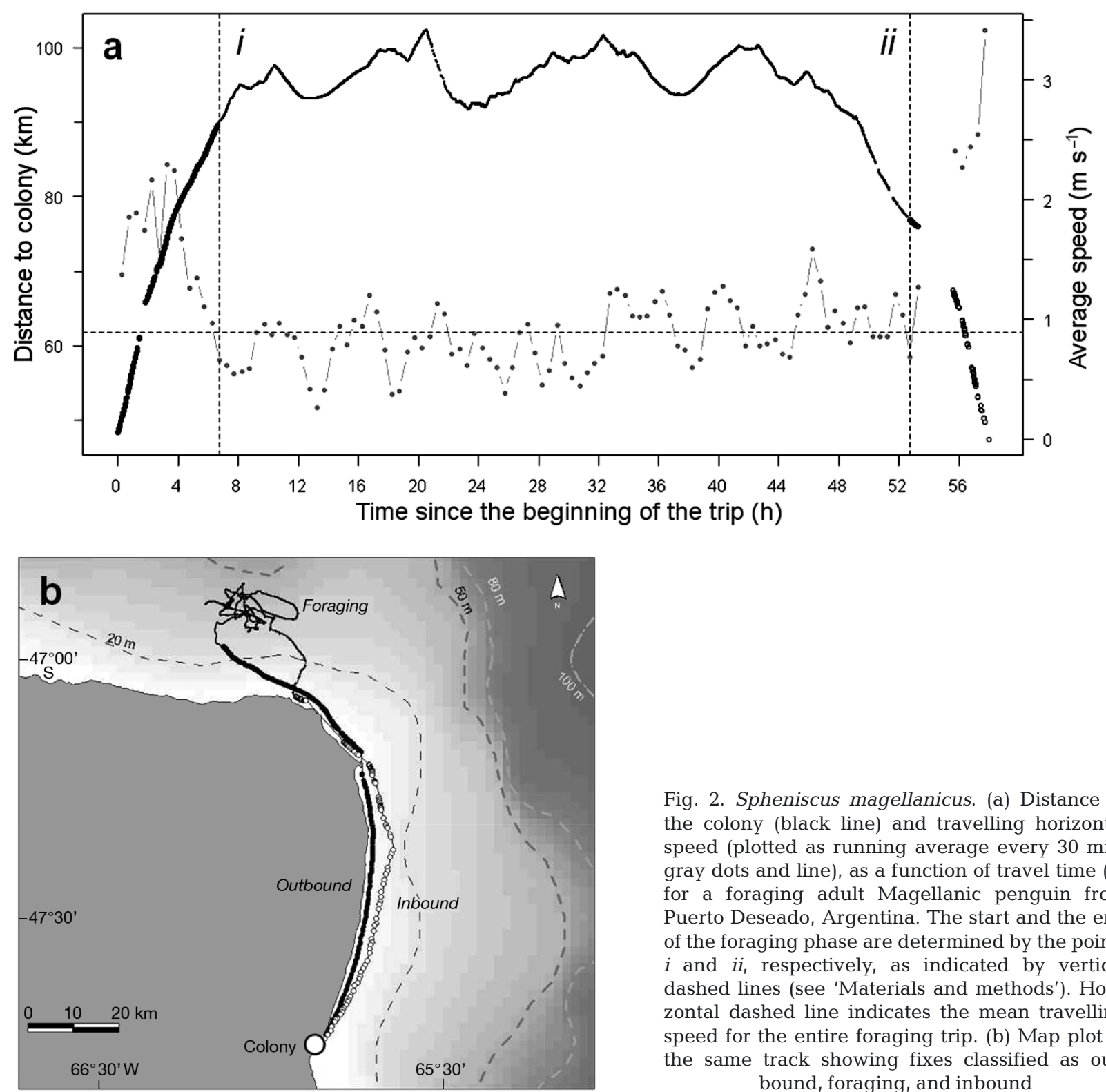

Fig. 2. Spheniscus magellanicus. (a) Distance to the colony (black line) and travelling horizontal speed (plotted as running average every $30 \mathrm{~min}$, gray dots and line), as a function of travel time (h) for a foraging adult Magellanic penguin from Puerto Deseado, Argentina. The start and the end of the foraging phase are determined by the points $i$ and $i i$, respectively, as indicated by vertical dashed lines (see 'Materials and methods'). Horizontal dashed line indicates the mean travelling speed for the entire foraging trip. (b) Map plot of the same track showing fixes classified as outbound, foraging, and inbound

line distance between the first and last location for the phase by the total distance that the penguin swam in that segment (the sum of the distances between adjacent locations). If a penguin swam in a straight line, the NTGDR was 1 . The more the penguin deviated from a straight line, the closer the NTGDR was to 0 .

\section{Rates of population change}

Magellanic penguin colonies are widespread along the Argentinian Patagonian coast spanning $>2200 \mathrm{~km}$ of coastline from $41^{\circ}$ to $54^{\circ} \mathrm{S}$ (Schiavini et al. 2005). The approximate size of the breeding population is known for most sites, but in many cases population trends are unknown (but see Schiavini et al. 2005). We used published data (counts of breeding pairs) to assess changes in breeding population size of our 5 study colonies and Punta Tombo, using data from Schiavini et al. (2005), Boersma (2008) and E. Frere (unpubl. data) (Table 1). Comparisons between foraging effort variables with population change were made using recent population growth rates calculated from available counts between 1992 and 2008 ( $\mathrm{n}=2$ to 15 counts per colony). Population size index values from Punta Tombo were derived from Fig. 9 in Boersma (2008) by using the graph 
digitizer software xyExtract 5.1 (freeware by Wilton P. Silva, available at wiltonps@uol.com.br). This index represents the number of active nests, which is very similar to the number of breeding pairs used for the other colonies.

\section{Statistical analysis}

Average values below are given with \pm 1 SD. In cases where we had data from more than one breeding season (Bahía Bustamante and Isla Martillo), these were compared using the nonparametric Mann-Whitney $U$-test (Zar 1999). When significant differences between colonies were detected with the nonparametric Kruskal-Wallis (KW) test, the differences among means were tested by Dunn's post hoc contrasts (Zar 1999). When it was necessary to compare colony pairs, we used nonparametric MannWhitney tests (Zar 1999). Proportional data (e.g. NTGDR) were averaged for individual penguins, arcsin-transformed to normalize them, and used in a KW test with a Dunn's multiple comparisions post hoc test to compare between colonies and trip segments (Zar 1999).

\section{Database}

Although we did not undertake a specific study to document potential effects of our handling or device attachment to the penguins, we observed no obvious differences in behaviour between our GPS-equipped birds and unequipped conspecifics. In particular, we did observe device-equipped birds feeding chicks, indicating that our study penguins had fed at sea.

We recorded a total of $1589 \mathrm{~h}$ at sea from 55 penguins equipped with GPS loggers comprising 1782030 fixes and completing a total of 58 foraging trips (completely or partially recorded). Most penguins (52 of 55) performed just a single foraging trip during the instrumented period although 3 birds performed 2 foraging trips ( 2 from Puerto San Julián and 1 from Isla Martillo; Table 2). While all foraging trips $(\mathrm{n}=58)$ were used to perform kernel contours, only those in which almost the entire track was recorded $(\mathrm{n}=44)$ were used to calculate the foraging variables (e.g. trip duration, length). We had 2 cases (from Puerto Deseado) of battery exhaustion before the start of the inbound phase owing to the very long foraging trips undertaken by birds from this colony (see below). Here, trip phases could not be properly distinguished, reducing our full data set to 42 foraging trips. Since there were no differences between measured parameters (e.g. trip duration, length and maximum foraging range) as a function of year (for breeding sites with more than 1 yr of records: Bahía Bustamante and Isla Martillo), data from all breeding seasons were pooled (Mann-Whitney $U$-tests: $Z=4.0$ to 7.0 and 3.0 to 7.0 for Bahía Bustamante and Isla Martillo, respectively; all $\mathrm{p}>0.05$ ).

\section{RESULTS}

\section{General foraging pattern}

During foraging trips penguins performed mainly 'direct return trips' ( $72 \%$ of cases), going straight to particular foraging areas and then returning to the colony, following essentially the same path or a path parallel to that of the outward leg (Fig. 3a). In contrast, the remaining $28 \%$ of the birds conducted 'loop-shaped trips', with clearly different legs for the departure and return phases of the trips (Fig. 3b). Birds from the southern colonies (Puerto San Julián and Isla Martillo) performed proportionally more direct return trips than those at other colonies (e.g. $89 \%$ from Isla Martillo vs. $50 \%$ from Puerto Deseado). Direct return trips had a greater tortuosity of displacement (greater NTGDR) in the foraging areas than did the loop-shaped trips $(0.23 \pm 0.21$ vs. $0.39 \pm$ 0.21 , respectively; Mann-Whitney $U$-test: $Z=90.50$, $\mathrm{p}=0.01 ;$ Fig. 3).

\section{Distribution at sea and foraging areas}

Penguins from Punta Norte, the northernmost colony, swam to the northeast where they exploited a distinctive area located between 25 to $65 \mathrm{~km}$ from the coast of Península Valdés (Fig. 4a). In both study years, birds from Bahía Bustamante foraged in areas located south of the colony, mostly following the coastline (Fig. 4b). Foraging tracks of Puerto Deseado penguins were less consistent, with penguins swimming in various directions (north, northeast and east, Fig. 4c). In general, individuals from Puerto San Julián moved along the coastline both to the south $(\sim 40 \%)$ and to the north $(\sim 60 \%)$ of their colonies (Fig. 4d). However, one of the birds performed a clear 'loop-shaped trip' to a more pelagic area at the northeast (Fig. 4d). Finally, breeding penguins from Isla Martillo, the southernmost colony, travelled in a southeast direction towards the the mouth of the Beagle Channel (Fig. 4e). 


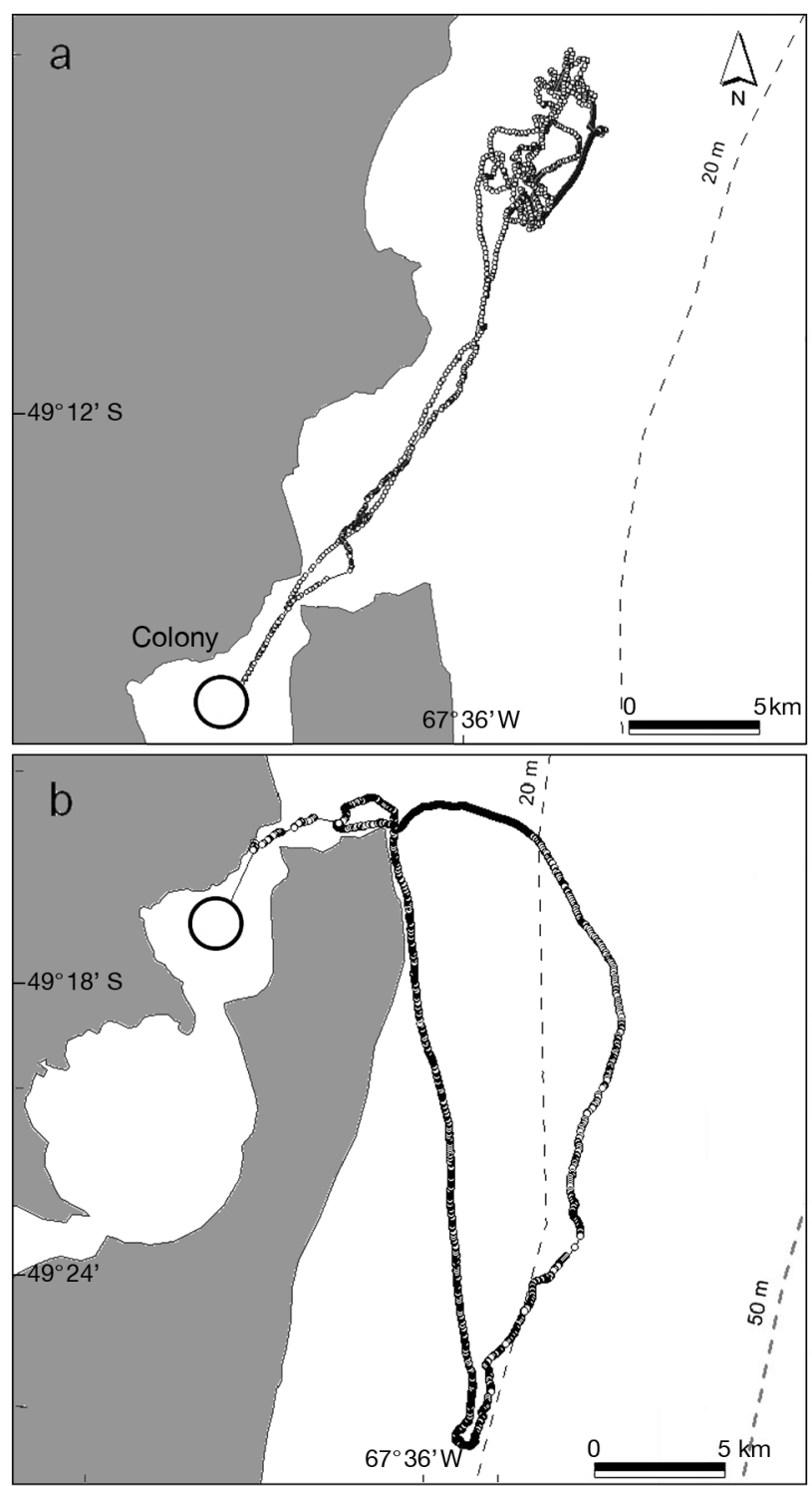

Fig. 3. Spheniscus magellanicus. Example of (a) 'direct return trip' and (b) 'loop-shaped trip' (see 'Results: General foraging pattern') from 2 adult Magellanic penguins from Puerto San Julián, Argentina

The main utilization areas of adult breeders from the 5 nesting sites were estimated as kernel probability contours of 50, 75 and $95 \%$ (Fig. 4). The major foraging area $\left(2093 \mathrm{~km}^{2}\right.$, kernel contour of $\left.95 \%\right)$ of Magellanic penguins from Punta Norte was located at the northeast of Península Valdés $\left(41^{\circ} 35^{\prime}\right.$ to $42^{\circ} 10^{\prime} \mathrm{S}, 63^{\circ} 08^{\prime}$ to $63^{\circ} 57^{\prime} \mathrm{W}_{\text {; Fig. }} 4 \mathrm{a}$ ). Two important marine areas (kernel contours of $95 \%$ ) of a total of $2525 \mathrm{~km}^{2}$ were identified for penguins from Bahía Bustamante: one was located to the east of the the colony in the north of Golfo San Jorge, while the other occupied a wide coastal sector to the south and southwest (Fig. 4b). Positions at sea from the 4 birds instrumented at Puerto Deseado highlighted 4 small areas (95\% kernel contours) occupying a total of $1188 \mathrm{~km}^{2}: 2$ were located close to the colony in an east-northeasterly direction, one was to the south of Golfo San Jorge (100 km to the north of the colony) and one was to the east-southeast at a maximum distance of $70 \mathrm{~km}$ from the colony (Fig. 4c). The main area of activity for birds from Puerto San Julián was located adjacent to the colony in coastal waters to the north and south of the breeding site (Fig. 4d). Another secondary, and smaller, area was situated $30 \mathrm{~km}$ to the northeast. Together, these sites covered $1063 \mathrm{~km}^{2}$ (Fig. 4d). The only area used by penguins from Isla Martillo was in the waters inside the Beagle Channel and covered $628 \mathrm{~km}^{2}$ (Fig. 4e).

There was a significant and positive linear relationship between the actual density of foraging birds within the areas bounded by the 95\% kernel contours and the proportion of 'direct return trips' among colonies $\left(\mathrm{R}^{2}=0.95, F_{1,4}=49.96, \mathrm{p}=0.0058\right)$, of which the more southern colonies (Puerto San Julián and Isla Martillo) had the highest densities and most direct return trips exploiting the smallest feeding areas.

\section{Foraging behaviour}

During the early chick-rearing period, penguins from the 5 studied colonies travelled distances ranging between $31 \mathrm{~km}$ (Isla Martillo) and $283 \mathrm{~km}$ (Puerto Deseado), while trip duration ranged from ca. 8 (Isla Martillo) to 74 h (Bahía Bustamante) (Table 3). Maximum foraging distances varied by almost an order of magnitude and ranged from $14 \mathrm{~km}$ (Isla Martillo) to $120 \mathrm{~km}$ (Bahía Bustamante). The maximum distance that the penguins moved away from the shore ranged from ca. $2.5 \mathrm{~km}$ (Isla Martillo) to $74 \mathrm{~km}$ (Puerto Deseado) (Table 3).

Overall, foraging trips can be classified into 2 different latitudinal patterns according to distances travelled. Penguins from northern (Punta Norte) and central (Bahía Bustamante and Puerto Deseado) colonies travelled farther and longer than those of the southern colonies at Puerto San Julián and Isla Martillo (KW: $H_{4}=19.97, \mathrm{p}=0.0005$; Table 3, Fig. 4). Birds from Puerto Deseado travelled 2.6 times farther than those from Isla Martillo (Table 3) and had a maximum distance from the colony that was almost 3.5 times greater than for Isla Martillo (KW: $H_{4}=$ 19.40, $\mathrm{p}=0.0007$; Table 3). 

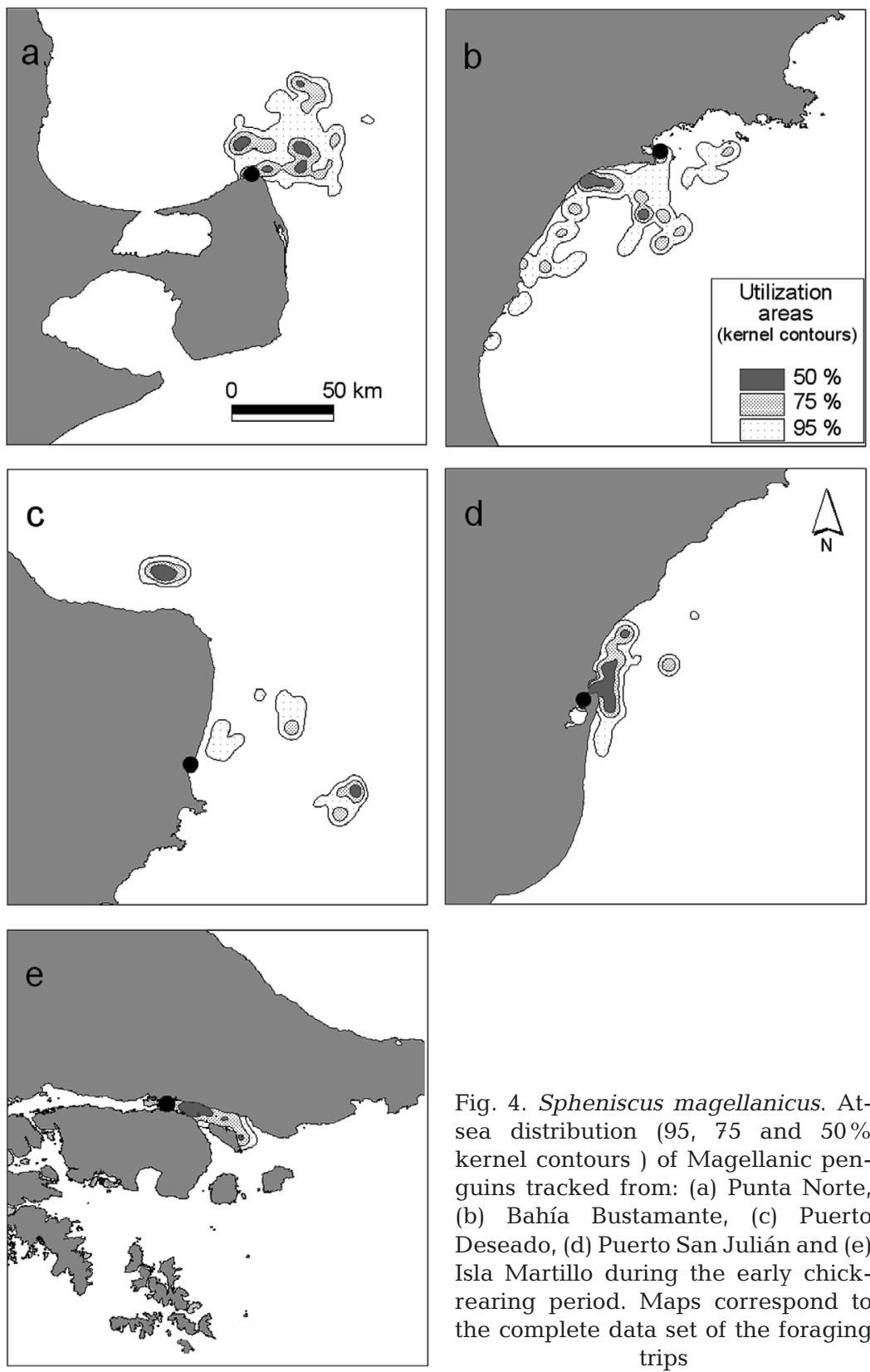

Fig. 4. Spheniscus magellanicus. Atsea distribution $(95,75$ and $50 \%$ kernel contours ) of Magellanic penguins tracked from: (a) Punta Norte, (b) Bahía Bustamante, (c) Puerto Deseado, (d) Puerto San Julián and (e) Isla Martillo during the early chickrearing period. Maps correspond to the complete data set of the foraging trips

Penguins from the 2 central colonies spent longer at sea than birds from Punta Norte and the 2 southerly sites (KW: $H_{4}=11.21, \mathrm{p}=0.02$; Table 3 ) and, for example, penguins from Puerto Deseado spent a mean of $41.4 \pm 15.0 \mathrm{~h}$ at sea, about twice as long as birds from Punta Norte $(24.5 \pm 6.6 \mathrm{~h}$; Table 3$)$. The limited number of birds (4 ind.) equipped with GPS units at Puerto Deseado coupled with the lack of information on the complete foraging trips from 2 of these birds (due to the devices exhausting their batteries before the birds returned) meant that sample sizes giving comprehensive information on the foraging trip parameters were limited for this site. However, 5 Magellanic penguins from Puerto Deseado were equipped with temperature and depth recorders at the same time as our study birds as part of another study, all of which were at sea for between 20 and $>40 \mathrm{~h}$ (mean $30.3 \mathrm{~h}, \mathrm{~J}$. E. Sala et al. unpubl. data), confirming the excessively long foraging trips for this site.

Generally, trips of longer duration were positively correlated with birds travelling greater distances for birds from all colonies (Table 4). Penguins from the central colonies (Bahía Bustamante and Puerto Deseado) took longer to reach the foraging areas than did those from the other colonies (KW: $\mathrm{H}_{3}=$ 8.06, $\mathrm{p}=0045$; Table 5). These birds also spent longer in the feeding zones (KW: $H_{3}=9.11, \mathrm{p}=0.028$; Table 5). In Bahía Bustamante, for example, birds spent twice as long foraging as those recorded from Isla Martillo (22.8 vs. $11.1 \mathrm{~h}$ ). However, all birds returned to their nests rapidly, and no statistical differences were apparent between colonies in the time spent on the return leg of the trip $(\mathrm{p}=0.12 ;$ Table 5).

The distances covered for the outbound path length ranged from 17.9 to $57.5 \mathrm{~km}$ and differed between colonies (KW: $H_{3}=10.43, \mathrm{p}=0.015$; Table 5). The main differences were that penguins from Bahía Bustamente travelled twice as far to their foraging areas as did birds from Isla Martillo (Table 5). A similar pattern was found in the distance travelled during the foraging phase in which birds from Bahía Bustamante travelled farthest (69.3 vs. $31.1 \mathrm{~km}$ for Bahía Bustamente and Isla Martillo, respectively; KW: $H_{3}=9.57, \mathrm{p}=0.0226$; Table 5). The inbound path length also differed between colonies (KW: $H_{3}=$ $10.60, \mathrm{p}=0.012$; Table 5), and penguins from the southern colonies (Puerto San Julián and Isla Martillo) travelled only about half the distance than the more northerly birds did (Table 5).

The time spent in the foraging area was positively related to the distance between the colony and the foraging ground, both when all 5 colonies were pooled $\left(F_{1,41}=19.33, \mathrm{p}<0.0001, \mathrm{R}^{2}=0.32\right)$, as well as in each colony considered separately $\left(F_{1,3}=40.84\right.$, $\mathrm{p}=0.0078, \mathrm{R}^{2}=0.93$ ). 
Table 3. Spheniscus magellanicus. Characteristics of completed foraging trips performed by Magellanic penguins during the early chick-rearing period at 5 colonies in Patagonia, Argentina. Mean $( \pm \mathrm{SD})$ values are given, along with range (minimum-maximum). Data were derived from the GPS loggers. Significant statistical tests are shown in bold. Kruskal-Wallis (KW) test with a Dunn's multiple comparisions test was used to compare between colonies; footnotes describe colonies which significantly differ from each other ( $\mathrm{p}<0.05$ ). Sample size (number of birds) per colony is given in parentheses

\begin{tabular}{|c|c|c|c|c|c|c|c|}
\hline Parameter & $\begin{array}{l}\text { Punta } \\
\text { Norte (10) }\end{array}$ & $\begin{array}{c}\text { Bahía } \\
\text { Bustamante (9) }\end{array}$ & $\begin{array}{c}\text { Puerto } \\
\text { Deseado (3) }\end{array}$ & $\begin{array}{l}\text { Puerto San } \\
\text { Julián (11) }\end{array}$ & $\begin{array}{c}\text { Isla } \\
\text { Martillo (8) }\end{array}$ & $H_{\mathrm{KW}(\mathrm{df}=4)}$ & $\mathrm{p}$ \\
\hline Trip length (km) & $\begin{array}{l}128.30 \pm 39.83 \\
95.49-231.00^{\mathrm{a}}\end{array}$ & $\begin{array}{l}144.33 \pm 60.23 \\
73.07-247.61^{b}\end{array}$ & $\begin{array}{l}181.97 \pm 88.57 \\
116.60-282.80^{\mathrm{c}}\end{array}$ & $\begin{array}{l}95.70 \pm 26.28 \\
68.54-157.10\end{array}$ & $\begin{array}{c}69.56 \pm 32.39 \\
31.40-121.20^{\mathrm{abc}}\end{array}$ & 19.97 & 0.0005 \\
\hline Trip duration (h) & $\begin{array}{l}24.51 \pm 6.56 \\
19.40-41.22\end{array}$ & $\begin{array}{c}38.74 \pm 18.36 \\
15.56-73.76\end{array}$ & $\begin{array}{c}41.37 \pm 14.99 \\
28.81-57.97\end{array}$ & $\begin{array}{l}27.00 \pm 7.55 \\
19.28-42.11\end{array}$ & $\begin{array}{c}20.69 \pm 10.40 \\
8.04-35.94\end{array}$ & 11.21 & 0.0243 \\
\hline $\begin{array}{l}\text { Maximum distance } \\
\text { from the colony }(\mathrm{km})\end{array}$ & $\begin{array}{l}45.35 \pm 12.47 \\
31.06-71.60^{\mathrm{a}}\end{array}$ & $\begin{array}{c}47.57 \pm 20.43 \\
24.66-83.21\end{array}$ & $\begin{array}{c}82.95 \pm 19.66 \\
63.06-102.36^{\mathrm{cd}}\end{array}$ & $\begin{array}{l}30.33 \pm 14.75 \\
15.45-67.87^{\mathrm{d}}\end{array}$ & $\begin{array}{l}24.31 \pm 11.82 \\
14.20-44.23^{\mathrm{ac}}\end{array}$ & 19.4 & 0.0007 \\
\hline $\begin{array}{l}\text { Maximum straight-line } \\
\text { distance from the coast }(\mathrm{km})\end{array}$ & $\begin{array}{l}40.27 \pm 12.44 \\
25.66-65.30^{\text {ae }}\end{array}$ & $\begin{array}{c}22.78 \pm 12.44 \\
4.73-39.96\end{array}$ & $\begin{array}{l}46.96 \pm 25.03 \\
24.39-73.88^{c}\end{array}$ & $\begin{array}{l}11.25 \pm 7.39 \\
5.30-34.66^{\mathrm{e}}\end{array}$ & $\begin{array}{c}5.90 \pm 2.88 \\
2.43-10.97^{\mathrm{ac}}\end{array}$ & 28.08 & $<0.0001$ \\
\hline
\end{tabular}

As expected, the NTGDR showed the highest values (least tortuosity) during the outbound and the inbound phase of the foraging trips (NTGDR mean ranges $=0.75-0.92$ vs. $0.20-0.34$ for commuting and foraging phase, respectively; Table 5). Penguins swam in almost straight lines (with NTGDR values close to 1) during the commuting phases but increased the tortuosity of the track (low values of NTGDR) during the foraging phase (Table 5, e.g. see Fig. 2b). Tortuosity during the inbound phase was similar for all colonies ( $p=0.53$; Table 5). However, penguins from Bahía Bustamante followed a significantly less straight line path during the outbound phase $(\mathrm{NTGDR}=0.75 \pm 0.16)$ than those made by birds from the other sites (KW: $H_{3}=9.99$, $\mathrm{p}=0.0186$; Table 5). Tortuosity during the foraging phase was similar between colonies $(p=0.44$; Table 5).

\section{Colony-specific rates of population change and foraging effort}

Examination of available colony counts over a period of $16 \mathrm{yr}$ allowed us to estimate the growth rate of each study colony as well as for Punta Tombo (see 'Materials and methods') (Table 1). The comparison among colonies of growth rate and colony size did not provide evidence of density-dependent growth in Magellanic penguin colonies $\left(R^{2}=0.18, p=0.40\right.$, $\mathrm{n}=6$ ). Moreover, colony size was not a good predictor of trip length, maximum foraging range and trip duration $\left(R_{\text {trip length }}^{2}=0.49, R_{\text {maximum foraging range }}^{2}=0.29\right.$, $\mathrm{R}_{\text {trip duration }}^{2}=0.30$, all $\mathrm{p}>0.25, \mathrm{n}=6$ ).

Foraging effort variables of penguins decreased with increasing rate of population change (Fig. 5): trip duration decreased with increasing colony growth rate $(p<0.05)$ (Fig. $5 a)$, total distance covered

Table 4. Spheniscus magellanicus. Summary of regression line parameters for the relationships between trip duration (TD, h) (dependent variable) and (a) trip length (TL, km), (b) maximum distance from the nest (MDN, km) (or foraging range) in Magellanic penguins from 5 study colonies. Significant statistical tests are shown in bold

\begin{tabular}{|c|c|c|c|c|c|c|}
\hline & Colony & Regression line & $\mathrm{R}^{2}$ & $\mathrm{r}$ & $F_{(\mathrm{df})}$ & $\mathrm{p}$ \\
\hline \multirow[t]{5}{*}{ (a) } & Punta Norte & $\mathrm{TD}=0.15 \times \mathrm{TL}+3.86$ & 0.82 & 0.91 & $36.74_{(1,9)}$ & 0.0003 \\
\hline & Bahía Bustamante & $\mathrm{TD}=0.30 \times \mathrm{TL}-3.91$ & 0.94 & 0.97 & $108.59_{(1,8)}$ & $<0.0001$ \\
\hline & Puerto Deseado & $\mathrm{TD}=0.21 \times \mathrm{TL}+1.90$ & 0.94 & 0.97 & $32.36_{(1,2)}$ & 0.03 \\
\hline & Puerto San Julián & $\mathrm{TD}=0.27 \times \mathrm{TL}+1.50$ & 0.86 & 0.93 & $67.11_{(1,12)}$ & $<0.0001$ \\
\hline & Isla Martillo & $\mathrm{TD}=0.31 \times \mathrm{TL}-0.93$ & 0.94 & 0.97 & $105.99_{(1,8)}$ & $<0.0001$ \\
\hline \multirow[t]{5}{*}{ (b) } & Punta Norte & $\mathrm{TD}=0.37 \times \mathrm{MDN}+7.90$ & 0.48 & 0.70 & $7.51_{(1,9)}$ & 0.02 \\
\hline & Bahía Bustamante & $\mathrm{TD}=0.85 \times \mathrm{MDN}-1.77$ & 0.90 & 0.95 & $61.45_{(1,8)}$ & 0.0001 \\
\hline & Puerto Deseado & $\mathrm{TD}=0.97 \times \mathrm{MDN}-41.99$ & 0.84 & 0.92 & $10.93_{(1,2)}$ & 0.08 \\
\hline & Puerto San Julián & $\mathrm{TD}=0.32 \times \mathrm{MDN}+17.24$ & 0.39 & 0.62 & $7.18_{(1,12)}$ & 0.02 \\
\hline & Isla Martillo & $\mathrm{TD}=0.67 \times \mathrm{MDN}+1.84$ & 0.76 & 0.87 & $18.76_{(1,8)}$ & 0.005 \\
\hline
\end{tabular}


Table 5. Spheniscus magellanicus. Summary statistics per colony of the track length, duration and net-to-gross ratio for each of the 3 foraging trip phases (outbound, foraging, inbound). Mean $( \pm \mathrm{SD})$ values are given, along with range (minimum-maximum). Data were derived from the GPS loggers. Significant statistical tests are showed in bold. Kruskal-Wallis (KW) test with a Dunn's multiple comparisions test was used to compare between colonies (see footnotes). Sample size (number of birds) per colony is given in parentheses

\begin{tabular}{|c|c|c|c|c|c|c|c|}
\hline Parameter & $\begin{array}{c}\text { Punta Norte } \\
\text { (10) }\end{array}$ & $\begin{array}{l}\text { Bahía Busta- } \\
\text { mante (9) }\end{array}$ & $\begin{array}{c}\text { Puerto San } \\
\text { Julián (11) }\end{array}$ & $\begin{array}{c}\text { Isla Martillo } \\
\text { (8) }\end{array}$ & $\begin{array}{c}\text { Puerto } \\
\text { Deseado }(1)^{\mathrm{a}}\end{array}$ & $H_{\mathrm{KW}(\mathrm{df}=3)}$ & $\mathrm{p}$ \\
\hline Outbound path length (km) & $\begin{array}{c}28.70 \pm 11.04 \\
7.53-46.22\end{array}$ & $\begin{array}{l}34.97 \pm 16.30 \\
18.23-68.05^{\mathrm{b}}\end{array}$ & $\begin{array}{l}21.03 \pm 7.33 \\
12.90-38.71\end{array}$ & $\begin{array}{r}17.87 \pm 10.09 \\
8.46-36.49^{b}\end{array}$ & 57.54 & 10.43 & 0.0153 \\
\hline Outbound time (h) & $\begin{array}{l}4.27 \pm 1.62 \\
1.78-7.63\end{array}$ & $\begin{array}{l}8.14 \pm 5.37 \\
3.81-20.73\end{array}$ & $\begin{array}{l}5.29 \pm 2.45 \\
2.69-11.25\end{array}$ & $\begin{array}{l}4.85 \pm 3.42 \\
1.75-11.24\end{array}$ & 6.64 & 8.06 & 0.045 \\
\hline Outbound net-to-gross ratio & $\begin{array}{l}0.91 \pm 0.06 \\
0.79-0.97^{\mathrm{c}}\end{array}$ & $\begin{array}{l}0.75 \pm 0.16 \\
0.47-0.92^{\mathrm{c}}\end{array}$ & $\begin{array}{l}0.83 \pm 0.11 \\
0.63-0.96\end{array}$ & $\begin{array}{l}0.89 \pm 0.08 \\
0.73-0.99\end{array}$ & 0.91 & 9.99 & 0.0186 \\
\hline Foraging path length (km) & $\begin{array}{l}58.76 \pm 16.73 \\
40.89-89.36\end{array}$ & $\begin{array}{l}69.34 \pm 33.55 \\
18.74-122.80^{b}\end{array}$ & $\begin{array}{l}50.77 \pm 18.27 \\
32.30-92.83\end{array}$ & $\begin{array}{c}31.07 \pm 27.40 \\
5.83-85.78^{\mathrm{b}}\end{array}$ & 183.97 & 9.57 & 0.0226 \\
\hline Foraging time (h) & $\begin{array}{r}13.52 \pm 5.02 \\
8.75-26.08\end{array}$ & $\begin{array}{r}22.82 \pm 11.44 \\
4.02-39.92^{\mathrm{b}}\end{array}$ & $\begin{array}{l}16.35 \pm 5.36 \\
11.48-29.90\end{array}$ & $\begin{array}{c}11.08 \pm 8.74 \\
2.76-28.39^{b}\end{array}$ & 45.95 & 9.11 & 0.028 \\
\hline Foraging net-to-gross ratio & $\begin{array}{l}0.32 \pm 0.20 \\
0.14-0.81\end{array}$ & $\begin{array}{l}0.34 \pm 0.29 \\
0.01-0.95\end{array}$ & $\begin{array}{l}0.20 \pm 0.14 \\
0.01-0.52\end{array}$ & $\begin{array}{l}0.24 \pm 0.20 \\
0.01-0.59\end{array}$ & 0.11 & 2.71 & 0.4382 \\
\hline Inbound path length (km) & $\begin{array}{l}41.14 \pm 21.49 \\
18.64-86.59\end{array}$ & $\begin{array}{l}40.02 \pm 18.72 \\
22.30-71.89\end{array}$ & $\begin{array}{c}23.91 \pm 11.13 \\
7.08-40.73\end{array}$ & $\begin{array}{l}20.62 \pm 11.28 \\
10.43-44.42\end{array}$ & 41.31 & 10.9 & 0.0123 \\
\hline Inbound time (h) & $\begin{array}{l}6.65 \pm 4.13 \\
2.19-15.65\end{array}$ & $\begin{array}{l}7.76 \pm 3.72 \\
4.37-15.89\end{array}$ & $\begin{array}{l}5.14 \pm 2.93 \\
1.19-12.88\end{array}$ & $\begin{array}{l}4.48 \pm 2.55 \\
2.36-10.04\end{array}$ & 5.21 & 5.79 & 0.123 \\
\hline Inbound net-to-gross ratio & $\begin{array}{l}0.85 \pm 0.11 \\
0.70-0.99\end{array}$ & $\begin{array}{l}0.83 \pm 0.13 \\
0.54-0.99\end{array}$ & $\begin{array}{l}0.83 \pm 0.15 \\
0.63-0.99\end{array}$ & $\begin{array}{l}0.92 \pm 0.05 \\
0.83-0.98\end{array}$ & 0.95 & 2.23 & 0.5253 \\
\hline
\end{tabular}

decreased with increasing growth rate $(p=0.06)$ (Fig. 5b) and the maximum distance reached decreased with increasing growth rate $(p<0.05)$ (Fig. 5c).

\section{DISCUSSION}

\section{General foraging patterns and colony-specific strategy}

Animals in an overall energetically steady state on a foraging trip should acquire enough energy to meet the energetic demands of the foraging process, the energy expenditure during the nonforaging period, and also provide enough food for appropriate brood growth. Under this scenario, a reduction in resource abundance will increase the duration of the foraging trip, primarily because more time must be spent acquiring food, and also because this necessarily longer period must also be paid for in acquisition of resources. Our results show considerable variation in the length of the foraging trips executed by Magellenic penguins from different colonies (Table 3), implying different prey acquisition rates. Since pen- guins acquire prey as a function of the distance they travel (Wilson 1985) and tend to travel at fairly constant speeds (Culik et al. 1994, Wilson \& Wilson 1995), the implication is that the birds spending longer at sea will also be travelling farther (Tables $3 \& 4$ ). A correlation between foraging trip duration and foraging path length (the cumulative distance for the whole foraging trip measured between positional fixes) has been reported for Adélie penguins $P_{Y}$ goscelis adeliae (Clarke et al. 1998) and king penguins (Wienecke \& Robertson 2002), as well as for Spheniscus penguins in general (Petersen et al. 2006, Raya Rey et al. 2010).

Given the strong link between foraging trip duration and distance covered, a primary determinant of the extent to which trip duration correlates with maximum distance to the colony will be the variation in directionality, or tortuosity, of the track. Our results show a tight correlation between foraging trip duration and maximum range (Table $4 \mathrm{~b}$ ), indicating overall similar tortuosity at the scale of the whole foraging trip. Similar correlations have been noted for king penguins (Wienecke \& Robertson 2002) and royal penguins Eudyptes schlegeli (Hull et al. 1997), as well as for Magellanic penguins from Punta Tombo 

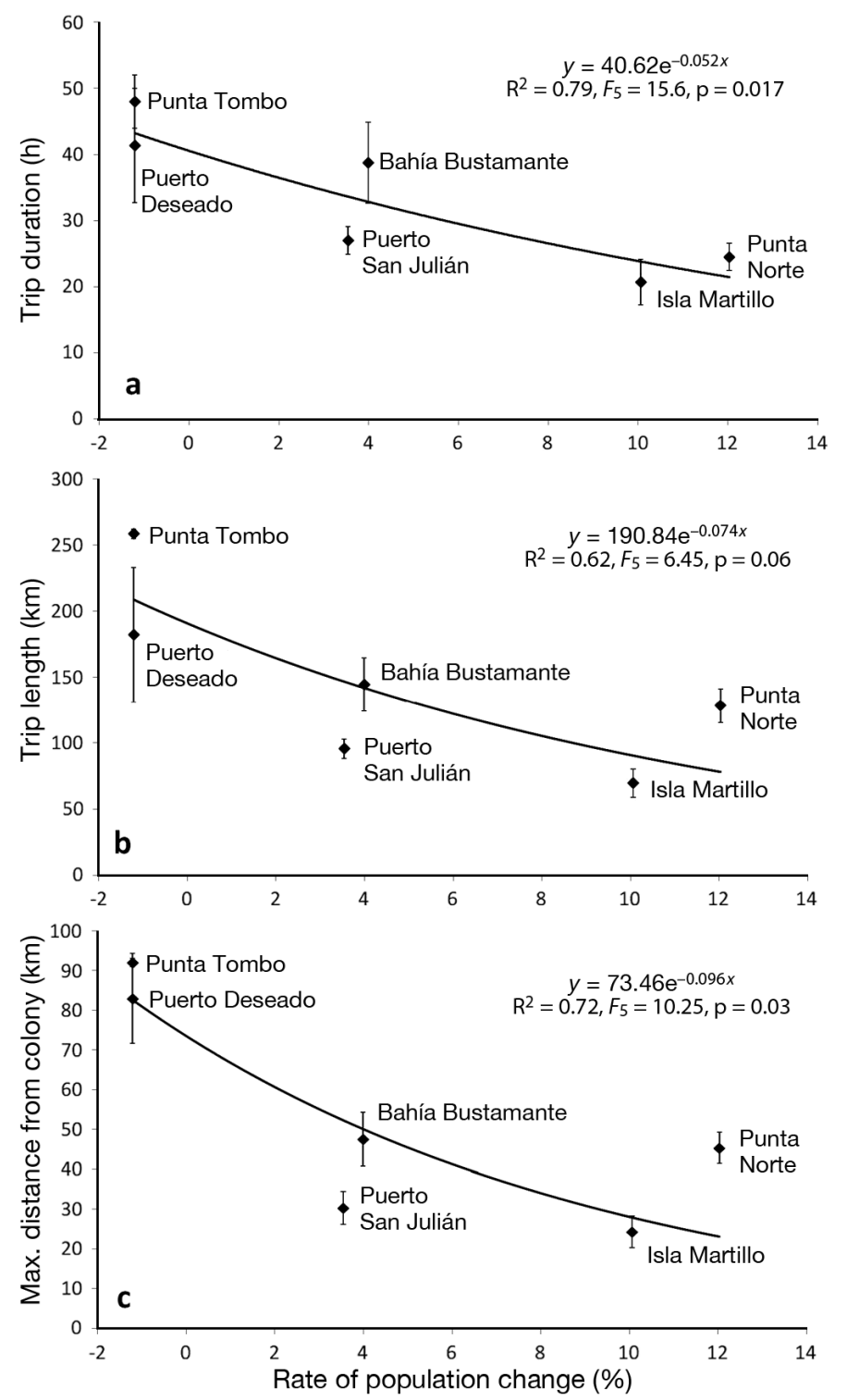

Fig. 5. Spheniscus magellanicus. (a) Trip duration $(\mathrm{h} \pm \mathrm{SE})$, (b) trip length ( $\mathrm{km} \pm \mathrm{SE}$ ) and (c) maximum foraging range $(\mathrm{km} \pm \mathrm{SE})$ in relation to recent population changes in 6 breeding sites of the Magellanic penguin from coastal Patagonia

(Boersma et al. 2007, Boersma \& Rebstock 2009) and Isla Martillo (Raya Rey et al. 2010).

The temporarily finely resolved data acquired using GPS systems enables us to refine our understanding of the features in penguin foraging patterns that lead to the observed intercolony variability beyond consideration of how maximum foraging distance relates to time away from the colony. As central place foragers (sensu Orians \& Pearson 1979), penguins have 3 distinct phases in their foraging trips: (1) a highly directional outward leg (Petersen et al. 2006,
Raya Rey et al. 2010), during which they execute short, shallow dives (cf. Wilson \& Wilson 1995), that serve to take the birds into likely foraging areas with minimum costs of transport (cf. Culik et al. 1994); (2) a foraging phase, where dives are longer and deeper and the overall speed of movement away from the colony drops substantially (Petersen et al. 2006, Boersma et al. 2009, Raya Rey et al. 2010); (3) a return phase, which is similar, in essence, to the outward leg (Raya Rey et al. 2010). Using these parameters we were able to define the characteristics of the different phases of the trip (see 'Materials and methods') and examine how they may relate to the observed patterns of population size and/or growth (e.g. Petersen et al. 2006, Boersma \& Rebstock 2009).

As in other studies, our data from Magellanic penguins showed 2 distinct elements in their foraging trips: a variable period of commuting to and from the foraging site and a variable period within the foraging site. The times allocated to these 2 elements (which are proportional to the distances travelled during those times) appear to play a key role in determining overall foraging success (cf. Orians \& Pearson 1979). In essence, the shorter any of these elements are, the better the conditions are for foraging and the more likely the population will do well because brood provisioning rates are higher (cf. RopertCoudert et al. 2004). Predictability of prey resources in space presumably plays a substantial role in this; it may be better for birds to travel farther to known areas of high prey density because the greater energy invested in transit can, nonetheless, be rapidly recouped. Some indication of the predictability of prey resources in space may be mirrored in the form of the track; birds may use areas with predictable high prey densities, therefore executing more direct trips, and may tend to use well-defined colony-specific areas that may have high bird densities. In this regard it is notable that this is exactly what our data showed, with the density of birds within the $95 \%$ kernel contours being related to the proportion of direct return trips (see above).

In a general sense, our data indicated that the most favourable conditions for foraging occurred in the north and the south of the species range, where transit time and presumed energetic costs were low. The short periods spent in the foraging area seem to indicate high rates of prey acquisition. The colony of Punta Norte differed from the other 2 range edge sites (Isla Martillo and Puerto San Julián) in having appreciably longer and therefore more energetically demanding transit phases, taking these birds substantial distances from the coast (Table 3, Fig. 4). 
However, the short times spent in the foraging areas would indicate this colony had one of the highest net rates of prey acquisition among any of the colonies (Tables $3 \&$ 5). It appears that, although the foraging areas were distant from the colony (Fig. 4), the productivity was such that penguins could feed rapidly to maintain a high provisioning rate of the chicks. Penguins from this site feed primarily on anchovy Engraulis anchoita (Frere et al. 1996b, Wilson et al. 2005), predominantly caught at tidal mixing fronts east of Península Valdés (Wilson et al. 1995, Acha et al. 2004).

This contrasts with the colonies to the far south (Isla Martillo and Puerto San Julián) where penguins from both colonies had lower transit costs, particularly the birds from Isla Martillo (Tables 3 \& 5, Fig. 4). This area has thermohaline fronts due to low-salinity water emanating from the Straits of Magellan and a recirculation cell in southern Santa Cruz Province where small pelagic fishes such as Fuegian sprat Sprattus fuegensis and silversides (Austroatherina sp. and Odonthestes smitti) (Sánchez \& Deciechomski 1995) spawn. Tidal mixing fronts also appear important for penguins further north where, for example, an inshore front delineates vertically mixed water from offshore, more stratified waters (Rivas et al. 2006, Boersma et al. 2009). Penguins from Puerto San Julián appear to use this area (Fig. 4). The movement of penguins from Isla Martillo, directed to the southeast, kept them close to the colony and the coast (Fig. 4, Table 3), where they presumably fed on their primary prey of the region, Fuegian sprat and lobster krill Munida gregaria (Schiavini et al. 2005, Raya Rey et al. 2010).

In contrast to the colonies at the edge of the species' distributional range, the 2 sites in the centre of the range (Bahía Bustamante and Puerto Deseado) had high transit times and long periods ascribed to foraging, which indicate low net rates of energy acquisition in the foraging area. Birds also showed more looping trips (see above). This presumably reflects reduced availability of prey close to these colonies, with the attendant implications for the colony (Forero et al. 2002). The generally centrenorth and centre-northwest directionality of tracks in the Golfo San Jorge (Fig. 4) by birds from Bahía Bustamante is probably due to penguins foraging in the spawning and nursery areas for anchovy and hake Merluccius hubbsi (e.g. Frere et al. 1996b, Rivas et al. 2006), themselves benefitting from tidal mixing fronts. Most penguins from Puerto Deseado appeared to forage in the waters that create fronts to the north where the coastal current interfaces with the coast
(Rivas et al. 2006, Boersma et al. 2009) although some birds used offshore areas (Fig. 4). All these results accord with movements reported by Boersma et al. (2009, their Fig. 3) and in the present study (Fig. 2b).

Where observed patterns are consistent over periods of years this implies stability in foraging conditions, although we note that many seabirds have to forage in oceanographic systems that display variability in time and space (cf. Weimerskirch 2007). Our limited data set does not allow us to consider variation in time in any detail, but we do note that the oceanography of the Patagonian Shelf is considered comparatively stable (Acha et al. 2004). This presumably accounts for the remarkable interannual consistency in the foraging routes taken by Magellanic penguins from Punta Tombo as documented by Boersma et al. (2009).

\section{Foraging effort and population trends}

Population growth rate is determined by the interaction of intrinsic and extrinsic effects (Lewis et al. 2001, 2006). Among colonial species, intrinsic processes are likely to be intensified during the breeding season due to the aggregations of individuals associated with colonies and obligate central-place foraging (Birkhead \& Furness 1985). Many studies have indicated that food availability around seabird breeding areas limits population sizes, but authors have found both density-dependent (Lewis et al. 2001, Forero et al. 2002) and density-independent mechanisms (Boersma \& Rebstock 2009) are important. We found no relationship between growth rate and colony size, indicating that extrinsic effects are the main determinant of recent population trends, there being no strong evidence for densitydependence in the study area and period.

Ashmole's halo hypothesis (Ashmole 1963) would predict that birds from the relatively small colonies of Bahía Bustamante and Puerto Deseado should be able to obtain their food requirements in shorter foraging trips closer to the colony than birds breeding in the larger colonies such as Puerto San Julián (Table 1). A consequence of individuals of larger colonies having to forage farther from the colony should lead to larger colonies growing slower than smaller ones (Grémillet et al. 2006). Our results found the opposite, with colony size being a poor predictor of trip length, maximum foraging range and trip duration, which is in accordance with data reported by Boersma et al. (2009). In practice, Ashmole's hypo- 
thesis would only be true if all resources were distributed evenly at all sites (Furness \& Birkhead 1984). Given the heterogeneity of marine resources (Weimerskirch 2007, Boersma et al. 2009; but see Forero et al. 2002) this is unlikely and our calculations do not support this.

According to Lewis et al. (2006), in the absence of any evidence that seabird colonies are being adversely affected by nest site availability, disease, predation and/or human disturbance (e.g. Boersma 2008 and references therein), rates of population change should be driven by food availability during the breeding season. At Punta Tombo-the colony with the largest rate of population decrease-the main cause of chick death is starvation (e.g. Boersma 2008 and references therein). When the extent of starvation is severe and continues over several seasons, recruitment to the colony is affected. Our study confirms this and supports the hypothesis by Lewis et al. (2006). It is probably significant that, in a recent study undertaken at Punta Tombo (Boersma \& Rebstock 2009), there was a clear negative relationship between the maximum foraging range (measured as maximum distance from the colony) and reproductive success. Apparently, birds foraging long distances cannot provision chicks at an appropriate rate, and this is exemplified by Magellanic penguins from Bahía Bustamante, which travel farther for food and have lower fledging success (Yorio et al. 2001) than birds nesting, for example, at New Island in the Malvinas/Falkland Islands, where foraging trips are shorter (Pütz et al. 2001, Boersma et al. 2002). Similarly, little penguins Eudyptula minor raising chicks at Motuara, New Zealand, made shorter trips and fledged significantly more chicks than those that bred at Oamaru (Numata et al. 2000).

Our results highlight the value of a mechanistic approach to understanding population processes. There was broad concordance across the variables we measured, with all relationships backing up each other with the majority being, in any event, statistically significant, which lends weight to our findings. Although our data are limited to a short time frame (early chick-rearing stage) and just 3 austral summers, it would seem that the relatively poor foraging conditions we inferred in the central region of the reproductive distribution (boundaries of Golfo San Jorge) may account for the observed lower population productivity of Bahía Bustamante and Puerto Deseado colonies (Fig. 5, Table 1). If our results are genuinely typical of the foraging conditions at the 5 sites studied, it is plausible that the slowing in population growth rates at Bahía Busta- mante and Puerto Deseado stems from the differences in food availability rather than any other process on land. Certainly, the results gained with the GPS loggers suggest that this is the case although local prey availability may not always be a good indicator of demographic parameters.

We have used this theoretical and empirical framework to evaluate population trends and foraging parameters of Magellanic penguins at a regional level. This case study indicates that foraging parameters can provide powerful indices of population health in the short term, and that such studies of foraging strategies in marine predators could therefore be an essential tool for management policies (e.g. Grémillet et al. 2006, Pichegru et al. 2007), although cognizance of other factors must always be given to provide a holistic picture.

Acknowledgements. Research was funded by grants from the Wildlife Conservation Society, Consejo Nacional de Investigaciones Científicas y Técnicas de la República Argentina (CONICET), and Agencia Nacional de Promoción Científica y Tecnológica to F.Q. and by a Rolex Award for Enterprise awarded to R.P.W. We especially thank P. Dell'arciprete for her technical assistance in spatial analysis. We thank M. Uhart, A. Raya Rey, A. Gómez-Laich, E. Shepard and V. Rago for field assistance. We also thank the respective Conservation Agencies from the provinces of Chubut, Santa Cruz and Tierra del Fuego for the permits to work in the different protected areas, and the Centro Nacional Patagónico (CENPAT-CONICET) for institutional and logistical support. J.E.S. was supported by a PhD fellowship from CONICET. This paper is dedicated to the memory of Néstor C. Kirchner (1950-2010), former President of Argentina, who revitalized and promoted the scientific Argentinean system, and to his wife, the current President, Cristina Fernández de Kirchner, who continues his legacy.

\section{LITERATURE CITED}

Acha EM, Mianzan HW, Guerrero RA, Favero M, Bava J (2004) Marine fronts at the continental shelves of austral South America: physical and ecological processes. J Mar Syst 44:83-105

Ashmole NP (1963) The regulation of numbers of tropical oceanic birds. Ibis 103:458-473

Bannasch R, Wilson RP, Culik B (1994) Hydrodynamic aspects of design and attachment of a back-mounted device in penguins. J Exp Biol 194:83-96

Beissinger SR, Westphal MI (1998) On the use of demographic models of population viability in endangered species management. J Wildl Manag 62:821-841

BirdLife International (2012) Species factsheet: Spheniscus magellanicus. Available at www.birdlife.org

Birkhead TR, Furness RW (1985) Regulation of seabird populations. In: Sibly RM, Smith RH (eds) Behavioural ecology: ecological consequences of adaptive behaviour. Blackwell, Oxford, p 145-167

Boersma PD (2008) Penguins as marine sentinels. Bioscience $58: 597-607$ 
Boersma PD, Rebstock GA (2009) Foraging distance affects reproductive success in Magellanic penguins. Mar Ecol Prog Ser 375:263-275

Boersma PD, Stokes DL, Strange IJ (2002) Applying ecology to conservation: tracking breeding penguins at New Island South Reserve, Falkland Islands. Aquat Conserv 12:63-74

> Boersma PD, Rebstock GA, Stokes DL, Majluf P (2007) Oceans apart: conservation models for two temperate penguin species shaped by the marine environment. Mar Ecol Prog Ser 335:217-225

Boersma PD, Rebstock GA, Frere E, Moore SE (2009) Following the fish: penguins and productivity in the South Atlantic. Ecol Monogr 79:59-76

Brown CR, Brown MB (2000) Heritable basis for choice of group size in a colonial bird. Proc Natl Acad Sci USA 97:14825-14830

Clarke J, Manly B, Kerry K, Gardner H, Franchi E, Corsolini S, Focardi S (1998) Sex differences in Adélie penguin foraging strategies. Polar Biol 20:248-258

Cotté C, Park YH, Guinet C, Bost CA (2007) Movements of foraging king penguins through marine mesoscale eddies. Proc Biol Sci 274:2385-2391

Croxall JP, Quintana F, Ferrari M (2008) Indicadores: tendencias de las poblaciones de especies seleccionadas. In: Estado de Conservación del Mar Patagónico y Áreas de Influencia. Puerto Madryn, Argentina, Edición del Foro. Available at www.marpatagonico.org

Culik B, Wilson R, Bannasch R (1994) Underwater swimming at low energetic cost by pygoscelid penguins. J Exp Biol 197:65-78

Duffy DC (1983) Competition for nesting space among Peruvian guano birds. Auk 100:680-688

Forero MG, Tella JL, Hobson KA, Bertellotti M, Blanco G (2002) Conspecific food competition explains variability in colony size: a test using stable isotopes in Magellanic penguins. Ecology 83:3466-3475

Frere E, Gandini P, Boersma PD (1996a) Aspectos particulares de la biología reproductiva y tendencia poblacional del pingüino de Magallanes (Spheniscus magellanicus) en la colonia de Cabo Vírgenes, Santa Cruz, Argentina. Hornero 14:50-59

Frere E, Gandini P, Lichtschein V (1996b) Variación latitudinal en la dieta del pingüino de magallanes (Spheniscus magellanicus) en la costa Patagónica, Argentina. Ornitol Neotrop 7:35-41

Furness RW, Birkhead TR (1984) Seabird colony distributions suggest competition for food supplies during the breeding season. Nature 311:655-656

García-Borboroglu P, Boersma PD, Ruoppolo V, Reyes L and others (2006) Chronic oil pollution harms Magellanic penguins in the Southwest Atlantic. Mar Pollut Bull 52:193-198

Gaston AJ, Ydenberg RC, Smith GEJ (2007) Ashmole's halo and population regulation in seabirds. Mar Ornithol 35:119-126

Girard I, Ouellet JP, Courtois R, Dussault C, Breton L (2002) Effects of sampling effort based on GPS telemetry on home-range size estimations. J Wildl Manag 66: 1290-1300

> Grémillet D, Pichegru L, Siorat F, Georges JY (2006) Conservation implications of the apparent mismatch between population dynamics and foraging effort in French northern gannets from the English Channel. Mar Ecol Prog Ser 319:15-25
Hull CL, Hindell MA, Michael K (1997) Foraging zones of royal penguins during the breeding season, and their association with oceanographic features. Mar Ecol Prog Ser 153:217-228

Hunt GL, Eppley ZA, Schneider DC (1986) Reproductive performance of seabirds: the importance of population and colony size. Auk 103:306-317

Lack D (1968) Ecological adaptations for breeding in birds. Methuen, London

Lewis S, Sherratt TN, Hamer KC, Wanless S (2001) Evidence of intra-specific competition for food in a pelagic seabird. Nature 412:816-819

Lewis S, Grémillet D, Daunt F, Ryan PG, Crawford RJM, Wanless S (2006) Using behavioural and state variables to identify proximate causes of population change in a seabird. Oecologia 147:606-614

> Numata M, Davis LS, Renner M (2000) Prolonged foraging trips and egg desertion in little penguins (Eudyptula minor). NZ J Zool 27:277-289

Orians GH, Pearson NE (1979) On the theory of central place foraging. In: Horn DJ, Mitchell RD, Stairs GR (eds) Analysis of ecological systems. Ohio State University Press, Columbus, OH, p 154-177

Petersen SL, Ryan PG, Gremillet D (2006) Is food availability limiting African penguins Spheniscus demersus at Boulders? A comparison of foraging effort at mainland and island colonies. Ibis 148:14-26

> Pichegru L, Ryan PG, van der Lingen CD, Coetzee J, RopertCoudert Y, Grémillet D (2007) Foraging behaviour and energetics of Cape gannets Morus capensis feeding on live prey and fishery discards in the Benguela upwelling system. Mar Ecol Prog Ser 350:127-136

> Pütz K, Ingham RJ, Smith JG, Croxall JP (2001) Population trends, breeding success and diet composition of gentoo Pygoscelis papua, Magellanic Spheniscus magellanicus and rockhopper Eudyptes chrysocome penguins in the Falkland Islands. Polar Biol 24:793-807

R Development Core Team (2011) R: a language and environment for statistical computing. R Foundation for Statistical Computing, Vienna

- Raya Rey A, Bost CA, Schiavini A, Pütz K (2010) Foraging movements of Magellanic penguins Spheniscus magellanicus in the Beagle Channel, Argentina, related to tide and tidal currents. J Ornithol 151:933-943

> Rivas AL, Dogliotti AI, Gagliardini DA (2006) Seasonal variability in satellite-measured surface chlorophyll in the Patagonian Shelf. Cont Shelf Res 26:703-720

> Rolland C, Danchin E, de Fraipont M (1998) The evolution of coloniality in birds in relation to food, habitat, predation, and life-history traits: a comparative analysis. Am Nat 151:514-529

Ropert-Coudert Y, Wilson RP, Daunt F, Kato A (2004) Patterns of energy acquisition by a central place forager: benefits of alternating short and long foraging trips. Behav Ecol 15:824-830

Sánchez RP, de Ciechomski JD (1995) Spawning and nursery grounds of pelagic fish species in the sea-shelf off Argentina and adjacent areas. Sci Mar 59:455-478

Schiavini A, Yorio P, Gandini P, Raya Rey A, Boersma D (2005) Los pingüinos de las costas argentinas: estado poblacional y conservación. Hornero 20:5-23

Weimerskirch H (2007) Are seabirds foraging for unpredictable resources? Deep-Sea Res II 54:211-223

Wienecke B, Robertson G (2002) Foraging area of king penguins from Macquarie Island in relation to a marine 
protected area. Environ Manag 29:662-672

Williams TD (1995) The penguins. Oxford University Press, Oxford

Wilson RP (1985) The jackass penguin Spheniscus demersus as a pelagic predator. $\mathrm{PhD}$ dissertation, University of Cape Town

Wilson RP, Vandenabeele S (2012) Technological innovation in archival tags used in seabird research. Mar Ecol Prog Ser 451:245-262

Wilson RP, Wilson MP (1995) The foraging behaviour of the African penguin. In: Dann P, Norman I, Reilly P (eds) The penguins: ecology and management. Surrey Beatty \& Sons, Sydney, p 244-265

Wilson RP, Scolaro JA, Peters G, Laurenti L, Kierspel M, Gallelli H, Upton J (1995) Foraging areas of Magellanic penguins Spheniscus magellanicus breeding at San Lorenzo, Argentina, during the incubation period. Mar Ecol Prog Ser 129:1-6

Wilson RP, Pütz K, Peters G, Culik BM, Scolaro JA, Charrassin JB, Ropert-Coudert Y (1997) Long-term attachment of transmitting and recording devices to penguins

Editorial responsibility: Jacob González-Solís,

Barcelona, Spain and others seabirds. Wildl Soc Bull 25:101-106

Wilson RP, Scolaro JA, Gremillet D, Kierspel MAM and others (2005) How do Magellanic penguins cope with variability in their access to prey? Ecol Monogr 75: 379-401

Wilson RP, Shepard ELC, Liebsch N (2008) Prying into the intimate details of animal lives: use of a daily diary on animals. Endang Species Res 4:123-137

Worton BJ (1989) Kernel methods for estimating the utilization in home-range studies. Ecology 70:164-168

Yorio P, García-Borboroglu P, Potti J, Moreno J (2001) Breeding biology of Magellanic penguins Spheniscus magellanicus at Golfo San Jorge, Patagonia, Argentina. Mar Ornithol 29:75-79

Yorio P, Quintana F, Dell'arciprete P, González-Zevallos D (2010) Spatial overlap between foraging seabirds and trawl fisheries: implications for the effectiveness of a marine protected area at Golfo San Jorge, Argentina. Bird Conserv Int 20:320-334

Zar JH (1999) Biostatistical analysis, 4th edn. Prentice Hall, Upper Saddle River, NJ

Submitted: January 13, 2012; Accepted: June 15, 2012

Proofs received from author(s): September 10, 2012 